\author{
Astrid Kovačević \\ Martina Kontuša 4, HR-51000 Rijeka \\ akovacevic2812@gmail.com
}

\title{
Spolno i jezično u opusu Adriane Cavarero: onkraj jednakosti i različitosti
}

U radu se razmatra odnos spolnog i jezičnog te njihov međusobni utjecaj unutar područja političke filozofije, lingvistike i teorije teksta, u pojedinim djelima Adriane Cavarero. Najprije se polazi od spoznaja poststrukturalističke teorije teksta, psihoanalitičkog feminizma i psiholingvistike, koje se potom proširuju rezultatima iz područja političke filozofije, s posebnim naglaskom na antičke tekstove. Analizom odabranih ulomaka Cavarerina opusa otvorit će se pitanje odnosa rodnog, spolnog i tekstualnog. Na temelju kritičkog čitanja Cavarerinih djela, teorijske literature i rezultata analize polaznih $i$ ciljnih tekstova, donijet će se zaključak o utjecaju spolnosti na jezik $i$ kulturu, odnosno o utjecaju jezika i kulturnih simbola na društvene i rodne uloge.
\end{abstract}

\section{Ključne riječi}

Adriana Cavarero, spolnost u jeziku, jezična demokratičnost, žensko pismo, psihoanalitički feminizam, materinji jezik, ženski subjekt, antički tekstovi

\section{Rodno, spolno, tekstualno}

Pisanje je čin subjekta koji govori, koji je uvijek višestruko uvjetovan, odnosno pod dubokim utjecajem

»... nesvjesnih ideoloških privrženosti te nesvjesnih emocionalnih uloga i fantazija, baš kao i svjesnih motivacija.« (Moi 2007: 243)

Pojedini autori iz područja filozofije, psihoanalitičke teorije, fenomenološke teorije subjektiviteta, poststrukturalističke teorije teksta i rodne teorije, razmatraju odnose spolnog, rodnog i tekstualnog te, suprotstavljajući se »romantičkim teorijama intencionalnosti«, nastoje razotkriti utjecaje i učinke tjelesnog i psihološkog na diskurzivno i performativno (Moi 2007: 242).

Sedamdesetih i osamdesetih godina prošloga stoljeća, ponajviše pod utjecajem frojdovske i lacanovske psihoanalize, ali i jungovske analitičke psihologije, proučavanje nekih osobitih karakteristika ženskog pisma i komunikacije nameće se kao relevantna tema u akademskoj zajednici. ${ }^{1}$ Mnoge znanstvenice, razvijajući alternativan, izvan-tekstualan ginocentrični ${ }^{2}$ pristup tekstovima u ženskom autorstvu, a oslanjajući se prvenstveno na ona područja koja

1

Osobito kod autora francuske poststrukturalističke teorije (Moi 2007: 145-230).

Sedamdesetih se godina dvadesetog stoljeća znanstveni pristup umjetničkoj produkciji bitno mijenja. $\mathrm{U}$ tom razdoblju dominantan trend postaje ginocentrični istraživački pristup, odnosno nakon 1975. godine znanstveni interes počinju sve više zaokupljati djela spisateljica (Moi 2007: 77-78). Ta faza istraživanja obilježena je produkcijom tekstova pomoću kojih autorice nastoje odrediti žensku tradiciju, inzistirajući na tezi da ona ipak proizlazi iz još 
su u najvećoj mjeri pridonijela razumijevanju ženske supkulture (poput: antropologije, psihoanalize, lingvistike i kulturalnih teorija), nastoje razotkriti prirodu i dinamiku ženske tekstualne i komunikacijske strategije. ${ }^{3}$

Dekonstrukcijom jezičnih granica, analizom sintagmatskih i paradigmatskih osi, odnosno sintaktičkih i semantičkih mehanizama, došlo se do novih spoznaja o kvalitativnom i kvantitativnom udjelu rodnog i spolnog unutar tekstualnog. Govori se o analogijama između tjelesne morfologije i psihologije (Irigaray 1977), o dubokoj i intimnoj povezanosti žene s vlastitim tijelom, ${ }^{4}$ o ženstvenosti kao tekućem svojstvu u neprekidnom pokretu ${ }^{5}$ (suprotstavljenom krutoj i solidnoj falokratskoj znanosti) koje izmiče patrijarhalnoj logici (Cixous 1975: 253), što ženski erotizam, poimanje i način izražavanja emocija i žensku retoričku strategiju - le parler des femmes (Irigaray1977: 141) vraća u taktilni položaj koji se odupire procesima konačne fiksacije značenja. Pored toga, propituje se termin écriture féminine ${ }^{6}$ koji označava libidnu razinu ženstvenosti unutar tekstualnog prostora (Cixous 1975: 242), te pojam muževnog, ženstvenog i biseksualnog unutar jezičnog (Cixous 1975: 249). Unutar rasprava o jeziku i retoričkim strategijama pisanog izričaja uvode se novi termini, poput: placentalne retorike, ${ }^{7}$ nomadskog pisma ${ }^{8}$ i tranzicijskog subjekta (Battersby 1998: 1-4,7). Istražuju se načini na koje jezik gradi kategoriju spola, odnosno načini na koje politički sustav i njegovi simboli izravno sudjeluju u diskurzivnom konstituiranju subjekta i identiteta unutar različitih povijesnih i kulturnih konteksta (Butler 2000).

I dok su velik doprinos tom području istraživanja na francuskoj kulturnoj sceni pridonijela djela Luce Irigaray i Hélène Cixous, odnosno na anglosaksonskoj sceni djela Judith Butler, Christine Battersby i Rosi Braidotti, na talijanskoj sceni u najvećoj su mjeri pridonijeli tekstovi filozofkinje Adriane Cavarero.

Cavarero, danas redovita profesorica područja političke filozofije na Katedri za filozofiju Sveučilišta u Veroni, uz Luisu Muraro, ključna je osnivačica filozofske feminističke skupine Diotima, ${ }^{9}$ unutar koje aktivno sudjeluje sve do devedesetih godina 20. stoljeća, kada se zbog vlastitih »radikalno demokratskih" pozicija ipak odlučuje odvojiti. ${ }^{10}$ Tijekom studija, ali i kasnije specijalizacije, osobit interes Cavarero pokazuje za antičke tekstove na izvornom jeziku, osobito one grčke, kao i za djela Hobbesa, Lockea i Hegela. Ipak, njezinu je pozornost najviše privlačio Platon. Cavarero je gotovo čitavu karijeru u potpunosti bila posvećena Platonovim tekstovima i cjelokupnoj kritičkoj bibliografiji koja ga prati.

Na njezin je feministički, radikalno marksistički stav mlađih godina velik utjecaj izvršio studentski pokret 1968. godine, ${ }^{11}$ na kojem je aktivno sudjelovala i tijekom kojeg je, kako danas ističe, razvila svoja prva kritička i anti-autoritarna stajališta. Sedamdesetih godina dvadesetog stoljeća, nastavljajući svoj istraživački put usmjeren na Platonove tekstove, Cavarero dolazi u kontakt s djelima Hanne Arendt, autorice zahvaljujući kojoj je, ističe, izoštrila vještine kritičkog tumačenja književnih i filozofskih tekstova, proizvodeći u konačnici gotovo uvijek ekstremne i originalne političke pozicije. Veliko zanimanje pokazuje i za djela Michela Foucaulta, Jacquesa Derridaa, Waltera Benjamina i Emmanuela Levinasa, a znanje i interes u području filozofije jezika i spolnosti u jeziku, odnosno spolne razlike u jezičnom sustavu, duguje, tvrdi, prvenstveno djelima Luce Irigaray, Hélène Cixous i Judith Butler koju danas smatra svojom glavnom sugovornicom u znanosti. ${ }^{12}$

Osnovne misli i kontekst djelovanja Adriane Cavarero mogli bi se sažeti u tri ključne točke. Prva točka sastojala bi se od alternativnih i pomalo radi- 
kalnih interpretacija jezičnih i kulturnih simbola, kao i tumačenja i primjene tekstova Hanne Arendt na problematiku rodnih (i drugih) odnosa u suvremenom zapadnjačkom društvu. Druga točka, u kojoj se filozofija i lingvistika neprestance prepliću, bila bi sva njezina istraživanja vezana uz teoriju spolne različitosti i spolnih razlika unutar jezičnog prostora. Cavarerin pokušaj da usamljenom i apstraktnom filozofskom subjektu suprotstavi konkretan i tjelesan subjekt - subjekt označen vlastitim ljudskim urođenim potrebama za odnosima s drugim bićima, bila bi treća točka koja ujedno objedinjuje prethodne dvije.

\section{O materinjem, majčinskom i jeziku »drugog«}

Cavarero je u velikoj mjeri pridonijela razumijevanju i razvoju teorije spolne različitosti i seksualnosti u jeziku, s osobitim naglaskom na specifičan književni i filozofski jezični registar. U svim svojim teorijskim razmatranjima prati umjeren visokointelektualan i sofisticiran francuski feminizam koji, za razliku od anglosaksonskog, ne razdvaja žensko i muško od ženstvenog i mu-

promjenjivog odnosa između spisateljica i njihova društva. Na taj način specifično žensku percepciju svijeta smatraju odrazom njihovih iskustava unutar društva, a ne odrazom bioloških kvaliteta.

3

Krajem sedamdesetih godina dvadesetog stoljeća pojavilo se nekoliko većih studija o spisateljicama kao dijelu specifično ženske supkulture: »Neke bilješke o definiranju feminističke kritike« Annette Kolodny, objavljen u časopisu Critical Inquiry 1975. godine, »Luđakinja u potkrovlju« (1979.) Sandre M. Gilbert i Susan Gubar, te »Prema feminističkoj poetici« (1979.) i »Feministička kritika u divljini« (1981.) američke kritičarke Elaine Showalter.

4

Poput stidnih usana koje se neprekidno dodiruju i međusobno opće (Irigaray 1997:24).

Aluzija na pred-edipsko dijadno vrijeme, obilježeno majčinim tjelesnim tekućinama: amniotičkom tekućinom, kolostrumom i menstrualnom krvi.

Ženstveno pismo.

Autobiografski tekstovi spisateljica u kojima se autorice obraćaju nerođenom djetetu $u$ utrobi.

8

Talijanska znanstvenica Rosi Braidotti kreće od filozofskih postavki Gillesa Deleuzea i Félixa Guattarija o nomadizmu i razvija pojam nomadsko pismo. Braidotti definira ženu kao nomadski subjekt, odnosno kao subjekt u fazi tranzicije, koja započinje dolaskom postmodernog doba, a nomada kao vrhunskoga jezičnog poliglota koji kontinuirano nastanjuje područja u kojima se prepliću različiti jezici i izričaji. Nomad je, ističe Braidotti, jezični virtuoz, njegov stil suprotstavlja se ustaljenom, rigidnom i formalnom akademskom institucionaliziranom jezičnom izričaju, a često je obilježen mnogobrojnim preklapanjima različitih jezičnih stilova i registara, približavajući se govornom, a ne pisanom jeziku. Nomadska estetika uglavnom je usmjerena na demistifikaciju književnog jezika, na rušenje političkih i kulturnih enklava i na uočavanje svih onih nejasnih oblika hegemonije i opresije (Braidotti 2002: 22-60).

9

Lik Diotime preuzet je iz Platonova Simpozi$j a$, u kojem Sokrat opisuje svećenicu iz Matineje kao svoju vrhovnu učiteljicu. Skupina je utemeljena 1983. godine u Veroni, a članice su afirmirane filozofkinje akademske zajednice, koje, krećući od temeljnih postavki Luce Irigaray o spolnoj različitosti, pokušavaju rehabilitirati žensku i ženstvenu prisutnost $\mathrm{u}$ filozofskoj znanosti.

10

O čemu više govori u knjizi Democrazia Sorgiva (Cavarero 2019).

11

U Italiji poznat kao muovimento dei sessanttottini.

12

Za talijanski je prijevod Butlerine knjige Bodies That Matter. On the Discursive Limits of Sex, Cavarero napisala predgovor (Corpi che contano. I limiti discorsivi del sesso, prev. Simona Capelli, Feltrinelli, Milano). 
ževnog ${ }_{13}^{13}$ već usvaja termin différance ${ }^{14}$ pomoću kojeg, kao i njezine francuske kolegice, označava nedjeljivost biološko-morfološkog obilježja od simboličkog poretka koji subjekt zauzima.

Između 1987. i 1997. godine, Cavarero piše i objavljuje svoje najuspješnije znanstvene radove, a njezino prvo istraživanje seksualnih razlika u jeziku, »Per una teoria della differenza sessuale« (»Za jednu teoriju spolne različitosti «) iz 1987., ujedno je i najpoznatije. U njemu autorica podrobno analizira glavne uzroke i posljedice razlika u jeziku između dvaju spolova, a osnovno je težište cjelokupne analize prebačeno na problematiku rodnoga jezika ( $i l$ linguaggio di genere), odnosno na istraživanja različitosti u smislu društva i društvenih uloga, a ne spolnih i tjelesnih kategorija.

Cavarerin se rad tako u velikoj mjeri podudara s knjigom Patrizije Violi, Beskonačna jednina. Razmatranja o spolnim različitostima u jeziku (L'infinito singolare. Considerazioni sulle differenze sessuali nel linguaggio), objavljenom tek godinu prije Cavarerina rada, u kojoj Violi također analizira pojam različitost u jeziku iz feminističke, odnosno rodne perspektive.

Naglašavanje rodne, a ne spolne, različitosti, u jezičnim analizama obiju autorica od izuzetne je važnosti. Spolna se različitost simbolički očituje unutar jezika prvenstveno putem rodnih kategorija. U tom smislu, rod nije isključivo gramatička kategorija koja usklađuje spolnu kategoriju, nego predstavlja samostalnu semantičku kategoriju koja emanira određeni simbolizam vezan uz tijelo. Violi (Violi 1986: 41) i Cavarero (Cavarero 1987: 78) smatraju da je rod unutar jezičnog simbolizacija spolne različitosti, no da sam jezik predodređuje strukturu budućih spolnih uloga koje, ulazeći u ritam svakodnevne komunikacije, ostvaruju naknadnu jezičnu reprodukciju i smisao. ${ }^{15}$

Obje se autorice, krećući od binarne analize pa sve do dekonstrukcijske, u velikoj mjeri bave analizom muškog i ženskog, odnosno muževnog i ženstvenog odnosa. Premda bi muškost i ženskost, kao i muževno i ženstveno, ističe Violi, po svemu sudeći, trebali posjedovati jednak status, jednaka prava, ipak ih ne posjeduju. Naime, Violi smatra da »derivacijska veza $\aleph^{16}$ spaja, ali ujedno i razdvaja, muško od ženskog. Žensko i ženstveno derivacije su muškog i muževnog, a vlastiti smisao ostvaruju tek kao »negacija« na ono prvotno i izvorno (Beauvoir 2016: 165).

Razmatrajući koncept »različitosti«, Cavarero ide korak dalje isticanjem da žena ne posjeduje vlastiti jezik, nego posuđuje jezik onog drugog. Ona se tako ne osjeća - i ne može osjećati - osviještenom i sigurnom u nastojanju da vlastitim riječima prikaže svijet pa ponekad jednostavno "govori tišinom ¿ $^{17}$ (Cavarero 1987: 53). Materinji jezik, ${ }^{18}$ općeprihvaćena i uvriježena definicija prvog usvojenog jezika, smatra Cavarero, uopće ne postoji:

»Taj jezik ne postoji, jer jezik žene, prije svega, ne postoji.« (Cavarero 1987: 52)

Jezik koji prihvaćamo i usvajamo kao prvi, za žene je, na neki način, strani jezik usvojen prijevodnim putem. ${ }^{19}$ Lacanovska psihoanaliza, na koju se Cavarero oslanja, edipsku krizu predstavlja kao trenutak u kojem se stječu jezik i nesvjesno, kao trenutak

»... izlaska iz prededipskog područja imaginarnog te ulazak u simbolički prostor jezičnih zakona.« (Homer 2005: 25)

Ulazak u simbolički poredak znači prihvaćanje zakona Oca, odnosno znaka Falusa i njegove označiteljske uloge. Budući da je u zapadnom društvu Otac nositelj primarnog zakona,${ }^{20}$ onaj koji otvara vrata simboličkog svijeta jezika 
i kulture, omogućujući konstituiranje subjekta te uspostavu spolne razlike i identifikacije, kao i rađanje nesvjesnog prostora, Cavarero je u pravu kada tvrdi da institucija materinjeg, odnosno majčinskog jezika u naravi ne postoji. $\mathrm{U}$ tom jezičnom raskoraku, u prijevodnom međuprostoru, otvaraju se, tvrdi Cavarero, tišine koje govore jer

»... u tišini nijem je zvuk, ne riječ.« (Cavarero 1987: 53)

Iz tog razloga, ističe autorica, žene najčešće pribjegavaju poeziji, romanu i autobiografiji. ${ }^{21} \mathrm{Ti}$ im oblici omogućuju da prazne prostore nadopune vlastitim jezikom, da se ne osjećaju kao da »jesu jezik«, već kao da »posjeduju jezik « (Cavarero 1987: 55), jasno aludirajući na lacanovski koncept »bivanja Falusom « koji označava ženski položaj užitka (jouissance) izvan i onkraj jezika, te koji izmiče integraciji i označavanju simboličkog poretka, ${ }^{22} \mathrm{u}$ odnosu

13

Razdvajajući biološko određenje (spol) od kulturnog obilježja (rod).

14

Hélène Cixous, razmatrajući žensko i ženstveno unutar tekstualnog, ističe kako je ženstven tekst onaj tekst koji »radi na razlici«, na rušenju sustava binarnih opreka (Cixous 1998: 258). Falogokratičnoj strukturalističkoj teoriji binarnosti Cixous suprotstavlja dekonstrukcijski koncept »heterogene razlike« Jacquesa Derridaa. Naime, prema Derridau, značenje se ne proizvodi unutar zatvorenog matriksa binarnih opreka, već se ono oslobađa beskonačnim procesom igre označitelja. Kao argument vlastitim tvrdnjama, Derrida postavlja primjer Saussureova koncepta fonema, najmanje razlikovne jedinice jezika. Za fonem se, ističe Derrida, nipošto ne može tvrditi da postiže značenje svojom binarnom oprekom jer sami po sebi fonemi »p«, »k« ili »h« ne znače ništa. Kada bismo foneme na taj način izolirali i postavili u proces binarnih opreka, ne bismo uspostavili konačno značenje unutar jezika kao sustava znakova. Fonemi, međutim, sposobnost označavanja postižu uspostavljanjem razlikovnih odnosa. Ne postoji transcendentalno označeno, kojim se proces označavanja može konačno i zauvijek zatvoriti. Pojmovi, elementi sustava, sami po sebi ne znače ništa, ne posjeduju nikakvu bit i svrhu izvan sustava. I to je osnovno načelo Derridaove teorije o razlici, kao one koja priskrbljuje značenje, inzistirajući na sufiksu -ance (différance), kojim biva označena pisana riječ i koja se $\mathrm{u}$ francuskom jeziku razlikuje od -ence (différence), kojom Derrida označava govorenu riječ. I dok drugi termin, différence, označava isključivo različitost, prvi označava razliku u smislu odgode, odnosno događanja kao procesa koji se opire konačnoj fiksaciji (Derrida 2007: 298-299).

15

»Mi smo ti govoreni u jeziku, ne oni koji taj jezik govore.« (Lepschy 1989: 61)
Aludirajući na »Knjigu Postanka« iz Staroga zavjeta, trenutak u kojem se opisuje nastanak prve žene izvlačenjem muškarčeva rebra, na ženu kao »muškarčev neesencijalni dodatak« (Beauvoir 2016: 165).

17

Ovim se aspektom jezika ponajviše bavio francuski feminizam koji razlike u jeziku traži upravo u tišini: u interpunkciji, u razmaku, u ritmu i tonu, u praznom prostoru između redaka, u ekstratekstualnom.

18

U ovom slučaju, Cavarero koristi termin majčinski (lingua madre).

S naglaskom na činjenicu da izvornik zapravo i ne postoji.

20

Misli se prvenstveno na zabranu incesta.

21

Naime, osim što mnoge spisateljice nisu imale životna iskustva svojih muških kolega, te tako nisu mogle stvoriti ratne drame, političke traktate ili filozofske rasprave, o čemu je detaljno pisala Virginia Woolf u knjizi Vlastita soba, one već stoljećima prihvaćaju onakvu vrstu ekspresije koja prati njihov dnevni ritam i obaveze, služeći se jezikom koji u najboljoj mjeri karakterizira njihovu svakodnevicu. Žene, tako, najčešće odabiru vrlo intimne žanrove, poput pisma, dnevnika, autobiografije i ljubavnog romana. U njima će doći do izražaja emotivni brodolomi, obiteljske drame i tome slično.

22

Žena obilježena kao prostor seksualnog prodora. 
na koncept »posjedovanja Falusa«, dakle, posjedovanja zakona i jezika, koji u tom smislu, jedini označava mogućnost uspostave subjekta i tvorbu identiteta. Cavarerino ustrajanje na odvajanju koncepta majčinskog od materinjeg također je psihoanalitičkog predznaka. Naime, lingua madre, mother tongue ili tzv. Muttersprache, ${ }^{23} \mathrm{u}$ doslovnom hrvatskom prijevodu majčinski jezik, termin je koji najbliže označava ono što najčešće podrazumijevamo kada izgovaramo riječ materinji (lat. maternum). Uzima se da je to prvi usvojeni jezik, standardni ili dijalektalni izričaj, koji posjeduje opći gramatički ustroj i pravila, vlastiti rječnik i leksičko-semantička pravila. Posredno, izraz povezuje koncept domovine s majkom, označavajući pritom etničku i kulturološku pripadnost (Macola 2008: 195-201).

S druge strane, termin lingua materna, langue maternelle, odnosno materinji jezik, romanska je filologija u razdoblju poststrukturalizma počela odvajati od majčinskog. Koncept materinjeg jezika izazivao je, a izaziva i danas, brojne polemike, sukobe struja i škola, osobito u autora i autorica koji prate Lacanov rad i utjecaj, odnosno koji se frojdovskoj i lacanovskoj paradigmi žestoko protive. Temeljna točka prijepora, lacanovaca i teoretičara bliskih tzv. feminizmu razlika (il femminismo della differenza), kojemu pripada i skupina Diotima, jest teorija o razvojnom utjecaju koji materinji jezik pospješuje ili usporava pri usvajanju majčinskog jezika, odnosno prvog službenog jezika bliže okoline djeteta. Miller ističe kako je u lacanovskoj psihoanalizi langue maternelle, ili najčešće korištena kraća varijanta termina la langue, karakterističan način izražavanja dojenčeta i njegove majke u odnosu s njim. Taj je govor u najvećoj mjeri neverbalan, intenzivno afektivan i tjelesan, slabo informativan i referencijalan, popraćen neartikuliranim tepanjem i tzv. lalacijom. ${ }^{24}$ Majka ga najčešće koristi dok doji, kupa ili presvlači dijete, tj. u trenutku intimnijeg dodira s djetetom, što dodatno osnažuje tu jedinstvenu simboličku komunikaciju (Miller 1996: 20). Tu ambivalentnu neverbalnu homofoniju u jednome trenutku prekida upad verbalne, leksički i morfološki jasno regulirane, znakovne komunikacije koju predvodi znak Oca, odnosno znakovi i zakoni patrijarhalnog naslijeđa (Miller 1996: 20-25). No, da bi prijelaz s afektivnog simboličkog govora Majke na gramatički uređen znakovni jezik Oca bio adekvatan, la langue mora biti potpuno obrisan (Miller 1996: 25-34), odnosno da bi svijet Realnog postao dostupan, Imaginarni svijet majke i djeteta, stvoren fuzijom afekata i tjelesnog, mora biti srušen (Miller 1996: 35-39).

Takvoj se tezi o razvoju prvog jezika žestoko protive pripadnice feminističkih struja sedamdesetih i osamdesetih godina dvadesetog stoljeća, osobito one okupljene oko skupine Diotima. ${ }^{25}$ One su afektivne simboličke kompetentnosti, koje majka tjelesnim kontaktom prosljeđuje djetetu, smatrale nužnim preduvjetom, svojevrsnim propedeutičkim minimumom koji omogućava kognitivni razvoj i napredovanje verbalne komunikacije. U trenutku kada se mjestimične »lalacije« započinju povezivati, bivati sve fluidnije i određenije, kada se iskustvena saznanja okolnog svijeta započinju povezivati sa simbolikom dodira i afektivnog govora, stvara se prostor za upad sljedećeg razvojnog stadija - stadija verbalne znakovne komunikacije. U tom je smislu la langue, odnosno materinji jezik, skup simboličkih kompetencija koje nasljeđujemo od Majke (Muraro 2006). ${ }^{26}$ Ono je naše prvo iskustvo povezivanja afekata i znakova, temeljeno na bezuvjetnom povjerenju, koje nas priprema za naredna osluškivanja i davanja značenja stvarima i pojavama. Arhetipskim jezikom, materinji se jezik prenosi generacijama, stoga ističu potonje teoretičarke, nosi 
predznak urođenog te ostaje obilježen kao prvi i najvažniji korak k uspostavljanju znakovnog dijaloga sa stvarnošću (Zamboni 2006).

\section{O spolnom i jezičnom u antici}

Jezik književnosti, za razliku od jezika filozofije koji je, smatra Cavarero, tradicionalno monistički i patrijarhalno usvojen, predstavlja jezik tolerancije i uvažavanja, koji poznaje i priznaje razlike. Baveći se, prije svega, političkom filozofijom, Cavarero razmatra utjecaj kapitalnih djela antičke filozofije na razvoj modernog društva. U Usprkos Platonu (Nonostante Platone), prebirući po Platonovim i Homerovim djelima, autorica izdvaja nekoliko ženskih likova (Penelopu, Demetru i Diotimu) i njihove priče umata u novo ruho, ne bi li dokazala svevremenu snagu ovih kultnih figura antičke književnosti te činjenicu da je mitološki svijet matrijarhata gotovo nasilno ugušen pretežito mizoginim interpretacijama antičkih tekstova. Cavarero smatra da je zapadnoeuropska književno-kulturna tradicija naslijeđe simboličkog, nasilno uvedenog, patrijarhalnog kodeksa, utjelovljenog u nekoliko ključnih muških predodžbi, među kojima se ponajviše ističu Edip, Odisej, Polifem, Faust, Don Giovanni, Cirano i Werther. Kroz vrijeme, ti su likovi bivali sve snažniji. U trenutku prelaska iz antičkog svijeta mythosa u moderni svijet logosa, odnosno iz romantičarske vizije svijeta u sferu realizma, potonji su likovi, prema mišljenju autorice, ostvarili golem i nerealan profit, ostavljajući na marginama žensko i ženstveno.

Naime, grčki je svijet mythosa oblikovan po načelu mjesta, vremena i radnje, a s vremenom je snažno odijelio svijet glavnih likova u odnosu na njihov spol. Oni su ratnici, moreplovci, osvajači, veliki ljubavnici, uspješni pjesnici, utjecajni filozofi i političari. One su ljupke i krotke robinjice, poslušne i kući privržene domaćice, demoni ili svećenice, a njihovu misao, kao u slučaju Diotime, ${ }^{27}$ prenosi netko od poznatijih muških autora. Oni koračaju planinama, plove oceanima, love po šumama - one strpljivo kroje u osamljenom kutku vlastitog doma, čekajući onog stranca kojem više lik ne prepoznaju, onog koji je osjećaj doma odavno izgubio. U raspravi o Platonovu Fedonu (Fedon, 84ab), Cavarero nudi posve drugačiju interpretaciju Homerove Penelope, čije se naoko uzaludno čekanje pretvara u simboličko ujedinjenje svega onoga što filozofija jest kao prvenstveno muška disciplina. Platonov nas Fedon uvodi u zatvor gdje Sokrat provodi svoje posljednje trenutke života, razmišljajući o smislu konačne smrti, o njezinom uzvišenom poslanju na ovome svijetu. Za Sokrata je smrt krajnja nagrada životu jednog filozofa, ona će u potpunosti

23

Iako je njemački izraz u velikoj mjeri kompromitiran zbog njegove zlouporabe $\mathrm{u}$ razdoblju nacizma i širenja ideologije superiorne etničke i biološke pripadnosti, tj. mita o čistoj krvi i čistome jeziku (Jankowski 1992: 36).

24

Neki lacanovci koriste izraz lala jezik (lala langue).

25

Osim Adriane Cavarero, velik su i važan doprinos ovoj temi dale Elisabetta Rasy, Luisa Muraro i Chiara Zamboni.
26

Označena velikim slovom jer simbolizira odnos djeteta (ne nužno djeteta i osobe koja je to dijete rodila) i osobe koja tu funkciju obavlja. 27

U Platonovu Simpoziju (201d), filozofsku misao poznate svećenice prenosi Sokrat. 
razjediniti duh i tijelo te na taj način osloboditi um od okova materijalnog i tjelesnog, od svega onoga što sputava i otežava put k mentalnom uzvišenju, $\mathrm{k}$ uzvišenim idejama, k onim stvarima »koje uvijek jesu« (ta onta). To življenje radi smrti, smatra Arendt, u temeljima je zapadnjačke filozofske tradicije:

»... duž cijele povijesti zapadnjačke filozofije prisutna je jedinstvena ideja o svojevrsnom afinitetu između smrti i same filozofije." (Arendt 1987: 162)

Dok je Platon, smatra Cavarero, prvi među jednakima čiji se životni put običnim smrtnicima čini kao neprestana težnja k smrti (Cavarero 1990: 33). Na početku Fedona, Platon objašnjava glavno poslanje filozofije kao najuzvišenije umne discipline koja pripada muškarcima. Ona je jedina znanost koja u potpunosti oslobađa, ona jedina ima sposobnost imitirati smrt, odvojiti dušu od tijela i tako udaljiti čovjeka od prizemnih ovozemaljskih strasti, od boli i užitaka koje čovjeka čine životinjom (Fedon, 84a-b) jer svaka težnja za ujedinjenjem duha i tijela dovodi, smatra Platon, u propast, u pakleni perpetuum mobile koji metaforički prikazuje upravo kroz lik žene, Penelope, koja danju sastavlja (kroji), da bi noću rastavljala, pokušavajući ujediniti ono što su patrijarhat i filozofija, kao prvenstveno patrijarhalna znanost, rastavile. Penelopa svijet nanovo sastavlja, lobira za život, a ne smrt, i ne teži onozemaljskim idejama, već ovozemaljskim iskustvima. Njezin jezik nije jezik filozofskih bogova, već jezik stvarnosti i osjećaja. Njezin jezik stapa dušu i tijelo progovarajući u jednom jedinstvenom tonu koji prati ritam psykhē, ali i some. Kao žena prisutna je ovdje, u ovome trenutku, na ovome mjestu s kojeg progovara. Ona nije poput Talesa čiji je pogled vječno usmjeren u nebeska tijela, tako da ne opaža obližnji bunar. ${ }^{28}$ Ona je karnalna predodžba ovozemaljskog, ljupka i krotka robinjica iz Trakije koja Talesu pruža pomoć, dražesno se osmjehujući i na taj način ironično dovodeći u pitanje primat filozofske misli i svih onih tekovina koje ona u zapadnjačkoj kulturi i jeziku ostavlja.

Podsmjehuje se ona, dražesna i privlačna robinjica, piše Cavarero, ona koja nije ni boginja, ni kći Sunca, ni svećenica, ona koja pripada svijetu kuće i ognjišta, ona koja odlazi po vodu da bi očistila i skuhala, ona koja je od samih početaka označena stigmom drugosti, ona nepredočena u ontološkoj sferi poimanja bitka, ona koju se ne vidi kada se u ogledalu upiše riječ čovjek (Cavarero 1990: 58).

Zaokupljena pronalaskom glavnoga krivca za lošu sudbinu zapadnjačke filozofije, Cavarero raspravu o mizoginim interpretacijama grčke mitologije nastavlja interpretacijom mita o božici Demetri. Naime, kako Tilde Giani Gallino u »Velike Majke: uvod u mit i arhetip« (»Le Grandi Madri. Un'introduzione al mito e all'archetipo«) objašnjava, Demetra je univerzalni simbol Velike Majke:

»... apsolutnog božanstva, koje, jasno posjedujući tajne života i plodnosti, jedina ima moć da ih prenosi i umnožava.« (Gallino 1989: 8)

Kod Platona su, međutim, kako tvrdi Cavarero, prirodna sila i snaga, koje izviru iz Demetre, znakovito poremećene, a Kratil, djelo u kojem Platon posvećuje pažnju mitu o božici plodnosti, zasigurno je početak književno-kulturnog prelaska matrijarhata u patrijarhat. Mit o Demetri i Hadu opisuje božicu plodnosti kao vječnu toplinu i energiju koja stvara, kao onu koja odlučuje o životu. Ona je nježna majka prelijepe božice Kore u koju se zaljubljuje bog podzemlja Had - bog vječnog mraka i hladnoće, vladar pustoši i samoće. ${ }^{29}$ Had otima Koru iz majčinih ruku i odvlači je u podzemlje. Majka zbog toga tuguje i gubi svoju stvaralačku energiju te zemlja polako odumire. Nakon 
izvjesnog vremena, Had ipak pristaje na kompromis i periodično (u ljeto i proljeće) prati Koru u njenoj posjeti majci jer, kako Cavarero ističe:

»Demetra se ne zadovoljava činjenicom da je kći zbrinuta, ona je želi vidjeti, želi u njoj uživati.« (Cavarero 1990: 152)

Luce Irigaray smatra da mit o božici Demetri predstavlja ključan trenutak u razvoju antičke filozofske misli (Irigaray 1987: 151). On je prvi otvoreni šav prekinutih veza ženske genealogije, koji je u potpunosti odijelio žensko od nadolazećeg patrijarhalnog poretka te na taj način potpisao sudbinu zapadne kulture..$^{30}$ No, ako ovdje izuzmemo činjenicu da mit o božici Demetri govori, među ostalim, i o sposobnosti odnosno mogućnosti ženskog spola da donosi odluku o stvaranju ili o uništenju, da donosi na ovaj svijet sudbine u obliku obaju spolova (Cavarero 1990: 93-121), muškog i ženskog, možda se ipak ključnim elementom ove priče čini trenutak majčinog pogleda. Cavarero, naime, ističe važnost metaforičkog ključa koji otvara samu bit mita - ženama su prijeko potrebni uzajamni pogledi, uzajamna bliskost i prisutnost vlastitog spola (Cavarero 1990: 68-71).

Ne videći jedna drugu, žene ne vide jasno sebe. Pogled majke u kćeri pogled je žene u ženi. Vlastiti je spol za svaku ženu horizont njezina prepoznavanja, a vizualna komunikacija ženskome spolu omogućava vratiti one odlomljene krhotine, fragmente, ženskog identiteta koje je patrijarhalno društvo rasulo, jer

»... komunikacija među ženama prehranjuje se prvenstveno sučeljavanjem životnih priča, a ne konfliktom velikih ideja.« (Collin 1986: 37)

U konačnici, iskustva su ono što pokreće maštu i stvaralačke procese, što motivira umjetničku ekspresiju i produkciju. Iskustva bliskosti i pogleda. Život, egzistencija i opstanak ne podrazumijevaju vezu sa samim sobom, već vezu s okolnim svijetom, a »svatko od nas definira sebe tragajući za sobom po tom svijetu« (Beauvoir 2016: 66).

\section{O anatomiji ženskog pisma}

U knjizi Auto/biografsko Ja. Teorija i praksa feminističke auto/biografije (The Auto/biographical I. The Theory and Practice of Feminist Auto/biography), Liz Stanley sociološkim postmodernim i poststrukturalističkim feminističkim pristupom razmatra ženske i ženstvene narativne sposobnosti i metode, ističući uvijek prisutan ženski interes da se priče drugih žena, dakle, vlastitog spola, pročitaju i poslušaju. U pozadini svega toga, tvrdi Stanley, nalazi se želja za isticanjem vlastitih životnih iskustava, kao onima vrijednih spomena ili, kako ih autorica naziva, lives-with-meaning (Stanley 1992: 20).

28

U Platonovu Teetetu (174a), opisan je Talesov iznenadni pad u bunar dok je koračao gledajući u zvijezde. U pomoć mu je pristigla dražesna robinjica iz Trakije čiji je osmijeh $\mathrm{u}$ tom trenutku postao centar ove anegdote $\mathrm{i}$ metafora za nužnost razumijevanja ovozemaljskih iskustava i pojava.

29

Znakovito je kako je već Aristotel u potpunosti zaokrenuo ovu genealošku paradigmu antičke Grčke te često isticao žensku reproduktivnu funkciju kao pasivnu i hladnu, dok je mušku reproduktivnu funkciju uzdizao tvrdeći kako upravo ona svojom pokretljivošću i snagom daruje život (Sissa 1983: 81-145).

30

Kora, naime, prelazeći u muški poredak, u svijet kojim vlada znak Falusa, Lacanovim rječnikom iz prostora Imaginarnog u prostor Simboličkog, nije više Demetrina kći, već Hadova supruga, a njezina su djeca njegova djeca, noseći njegovo prezime. 
Američka i francuska postmodernistička kulturna scena, obje vrlo utjecajne, donose novitete na polju autobiografije, osobito one ženske, i to kako na polju naracije i same tehnike pisanja, tako i na polju interpretacije. Naime, smatra Cavarero, ono što se u znanosti o književnosti prepoznaje kao klasična autobiografija $^{31}$ podrazumijeva prisutnost jednog jedinstvenog, stabilnog, snažnog i nepokolebljivog subjekta, kompaktnog i ujedinjenog sebstva, koji se u toj vrsti autonaracije, na neki način, samopotvrđuje (Cavarero 1997: 91). U tom smislu, njegova je autobiografija svojevrsno ogledalo već izgrađenog i nadasve postojanog identiteta. Takav teorem klasične autobiografije, ističe Cavarero, govori o prisutnosti jednog sveznajućeg subjekta koji, pripovijedajući vlastiti život, preuzima ulogu prevoditelja prenoseći vlastita iskustva iz svijeta realnog u pisani medij svijeta fikcije, držeći pritom znatan odmak od svoje "psihološke esencije«, svoga vlastitog $J a$, u odnosu na tekst koji mu služi (Cavarero 1997: 92-100).

$\mathrm{S}$ druge strane, razdoblje postmodernizma i poststrukturalističke teorije $\mathrm{u}$ potpunosti je izmijenilo koncept autobiografskog. Janet Varner Gunn ističe kako se $\mathrm{u}$ antimetafizičkom horizontu poststrukturalističke teorije ne nazire postojanje univerzalnog i jedinstvenog $J a$ izvan jezičnih granica teksta, odnosno sam je tekst stvoritelj onog koji progovara, autora ili pripovjedača (Gunn 1982: 30). Tekst je taj koji donosi kontinuitet, stabilnost i jedinstvenost vlastitom $J a$, koje sada njemu služi. $J a$ je tako produkt teksta, rezultat performativne moći retoričkih tekstualnih strategija, a autorovo/pripovjedačevo sebstvo čisti je efekt moći jezika. U tom smislu, postmodernisti i postmodernistička feministička kritika u sintagmi autobiografsko kao ključan element ističu upravo graphein, a ne auto i bio. U poglavlju knjige Ti koja me gledaš, ti koja mi pripovijedaš (Tu che mi guardi, tu che mi racconti) naslovljenom »U jednoj njujorškoj knjižari« (»In una libreria di New York «), Cavarero analizira potonje dvije vrste autobiografskog izričaja i dolazi do zaključka kako su one uvelike određene spolnim razlikama (Cavarero 1997: 89-102). Naime, ženstven se pristup autobiografskom sastoji upravo od negiranja jedinstvenosti i nadmoći autorova $J a$ nad vlastitim tekstom, negirajući istodobno čitavu falogocentričnu zapadnjačku književno-kulturnu tradiciju koja sposobnost sinteze i unifikacije prepisuje $\mathrm{Njemu}$, dok istodobno

»... fragmentiranost, nedosljednost i rezistentnost na svaku moguću sintezu prepisuje Njoj.« (Battersby 1989: 151)

Ženske su biografije i autobiografije, smatra Cavarero, multifragmentirani slijed životnih segmenata, koji vlastito mjesto i značaj traže upravo u jeziku i tekstu. Taj život, koji čeka u redu da bude ispričan, svoj oblik i značaj ostvaruje tek unutar teksta koji ga kroji, odnosno u beskonačnim hermeneutičkim mogućnostima kojima raspolaže čitatelj/ica. Da bi što slikovitije prikazala ovu izuzetno važnu distinkciju između muške i ženske autobiografije, muževnog i ženstvenog autorstva, Cavarero ženski stvaralački proces uspoređuje s pričom iz romana Moja Afrika (Out of Africa) Karen Blixen. U romanu, naime, jedan od likova, čuvši neobične zvukove, u gluho doba noći diže se iz toplog kreveta, no zapinje i pada u blato. Vraćajući se u kuću, nakon što je popravio rupu koja je proizvodila buku, vlastitim cipelama ostavlja tragove u obliku rode. Probudivši se sutradan, ostaje šokiran onime što vidi:

»Kako li sam samo to uspio napraviti?«(Blixen 1959: 200)

Cavarero tumači kako je upravo ovom anegdotom Karen Blixen metaforički zapečatila ključ ženskog teksta - činjenicu da se njegov smisao krije upravo 
u jednom jednostavnom i nadasve spontanom slijedu okolnosti, u potpuno slobodnim i neovisnim narativnim sekvencama, bez ikakvih velikih projekata koji im prethode. Ukratko, zaključuje Cavarero, životne priče i puteve ne određuje konačni crtež, već životni putevi ostavljaju tragove koji možda mogu postati upravo taj crtež. To je oznaka retorike apsolutne slobode, lišene svih predrasuda i okova postojećih kanona.

\section{Kolonizacija ženskog subjekta}

Sve do kraja druge polovice prošloga stoljeća koncept »spolne različitosti«, kako u području prirodnih, tako i u području humanističkih znanosti, osobito frojdovske i lacanovske psihoanalize, uglavnom je temeljen na vizualnim pretpostavkama. Taj koncept označava vizualnu prisutnost, odnosno vizualnu odsutnost, normu ili otklon od iste. Vizura, zrcalna refleksija definira jedno biće superiornijim jer »posjeduje« i drugo biće inferiornijim jer mu očito nešto nedostaje (Irigaray 1974: 20). Irigaray ističe kako zrcalni odraz predstavlja ženu kao prazan prostor obavijen osjećajima žudnje i zavisti »za« i »prema« nečemu što ne posjeduje i/ili ne može doseći (Irigaray 1974: 70), a kako je za tradicionalnu frojdovsku psihoanalizu zrcalna refleksija ključna u formiranju identiteta jer njome bivaju uspostavljeni subjektni odnosi, zapadni filozofski diskurs vidi ženu kao »zrcalni odraz muškog subjekta«, a ženstvenost kao »negativ muževne refleksije« (Irigaray 1974: 20). Žensko i ženstveno postaju tako naknadne, sekundarne tvorevine, čija su svojstva podređena primarno prolaskom kroz imaginarij muškog. U tom smislu, muškarac je nositelj ženskog identiteta, a žena je psihološki ogoljena. Ona ne prepoznaje vlastiti identitet bez prisutnosti muškog subjekta. U odsustvu zrcalnog odraza, žena nestaje.

Upravo je ova razmatranja i stajališta Cavarero opisala u zbirci teorijskih tekstova pod nazivom Feministička razmišljanja. Teorijski pristup (Il pensiero femminista. Un approccio teorico), u kojoj nanovo optužuje zapadnjačku kulturnu tradiciju jer je pojmom različitost, u spolnom i jezičnom smislu, označila ne dvije jednako vrijedne i na istoj razini suprotstavljene ontološke biti, nego dva u potpunosti udaljena hijerarhijski strukturirana termina, od kojih je jedan nadređen i uključiv, a drugi podređen i isključiv (Cavarero - Restaino 2009a: 81). Taj se etablirani sustav znakova, ističe Cavarero, služi terminom različitost da bi isključivo ojačao i potvrdio univerzalni koncept čovjeka kao prvenstveno modela muškog roda, rođenog i razvijenog unutar bipolarne logike simboličkog poretka kojim isti vlada. Taj patrijarhalan sustav postavlja muškarca kao subjekta s oznakom cjelovitog sebstva, a njemu suprotstavlja ženu kao objekt s oznakom njegovog drugog, kao onog koji vlastitu poziciju traži i ostvaruje u odnosu na falusni centar:

»Ta druga, ne drugačija, već upravo druga jer nastaje nakon njega, prvog, nastaje za njega. Ta druga bez vlastite riječi, bez vlastitih znakova, koja zauzima mjesto u imaginariju koji joj ne pripadaju.« (Cavarero - Restaino 2009a: 84)

Cavarero, upravo iz tog razloga, patrijarhalnu zapadnjačku tradiciju smatra »homoseksualnom« jer je glavni i jedini akter simboličkog poretka isključivo muškarac, a jezik koji tu istu tradiciju strukturira i oblikuje smatra taocem androcentričnih, mizoginih pretpostavki. Osnovnu je tezu o zapadnjačkim 
kulturnim simbolima i jeziku koji gradi falogokratičan sustav razmišljanja, Cavarero ilustrativno prikazala i u poglavlju o Adamu i Evi, svoje posljednje knjige Naginjanja (Inclinazioni). U spomenutom poglavlju analizira dva poznata ulja na platnu, američkoga konceptualnog umjetnika Barnetta Newmana, izložena u muzeju moderne umjetnosti u Londonu, pod nazivom Adam $i$ Eva iz 1951., odnosno 1950. godine (vidi sliku 1). Cavarero skreće pozornost na široku centralnu vertikalnu os duž tamno označene pozadine (Adam) u odnosu na tanku marginalnu liniju koja kao da ne uspijeva zadržati i umiriti taj kaotičan i nemiran bezdan, tu prazninu koju je gotovo nemoguće omeđiti i oblikovati (Eva). Cavarero smatra da je Newman ovim apstraktnim prikazima iznjedrio esencijalnu paradigmu zapadnjačke kulturne tradicije; Eva je u ontološkoj sferi poimanja bitka označena kao praznina, upravo poput ulja na platnu koje kao da čeka da se u njega nešto upiše, da se doda jer žena još nije zadobila vlastiti oblik, vlastito mjesto, vlastitu ulogu u svijetu. Ona je i dalje ovdje, čeka da je se pronađe.

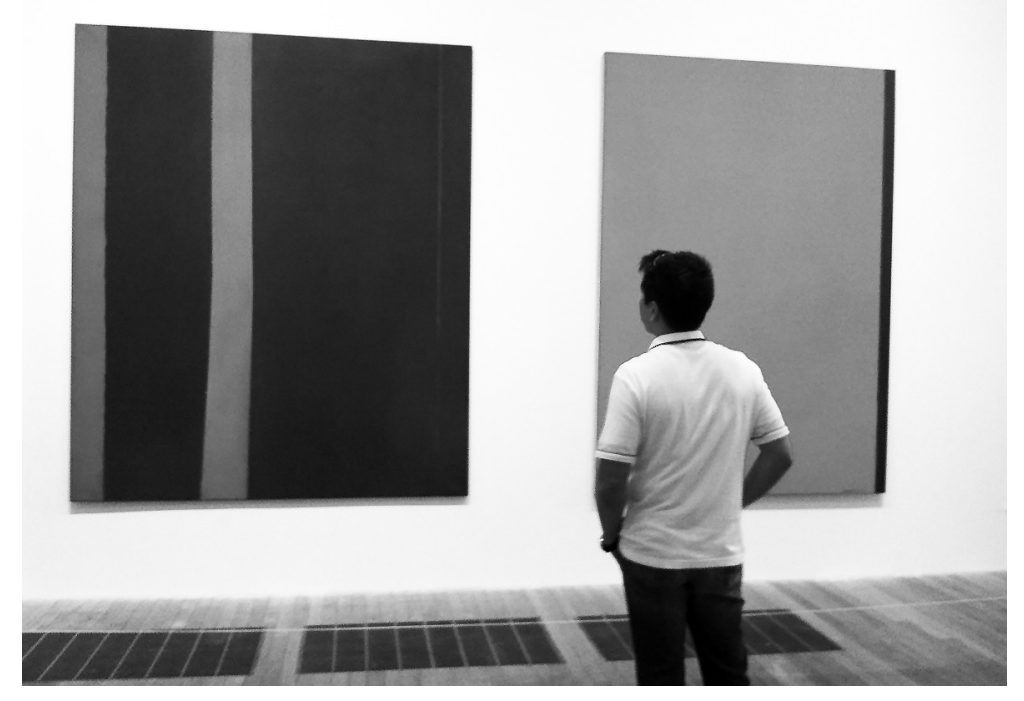

Slika 1: Lijevo: Barnett Newman, Adam (ulje na platnu, 1951.); desno: Barnett Newman, Eve (ulje na platnu, 1950.), muzej Tate Modern, London. Fotografirali članovi Snippets From The Manila Art Scene bloga.

Društvena i rodna svojstva, srž identiteta, oblikuju riječi. One postavljaju i otvaraju granice, uspostavljaju materijalnost subjekta. Lingvističkim pravcem usmjereni smo na razmišljanja o tome što netko »jest«. Jezične nas norme i zakoni, prije svega, zapadnjačke filozofije i metafizike, uvode u temeljna pitanja identiteta, spola i roda te njihovih međusobnih odnosa. ${ }^{32}$ Jezikom i komunikacijom ukazujemo na stanje u društvu, na društvene odnose, na odnose pojedinaca i kategorija. I ne samo to. Jezikom, iz dana u dan, to isto društvo izgrađujemo. No, jezik jest, iznad svega, semiološki fenomen (Saussure 2003: 95-96). Stoga, kao takav, izvan granica društvene stvarnosti, društvenih kategorija i uloga, ne postoji. Da bi jezik postojao, potreban je »onaj netko« tko se njime, na ovaj ili onaj način, služi.

Upirući prstom u filozofiju i lingvistiku, koje su, smatra Cavarero, u velikoj mjeri pridonijele marginalizaciji ženskog i ženstvenog, Cavarero nastoji ukazati na nužan odmak od prikrivenih androcentričnih teorija i zaključaka 
kako bi se stvorili preduvjeti za oformljivanje novog, jedinstvenog i različitog ženskog jezika. Iz pozicije političke filozofije, razmatrajući utjecaj jezika filozofije na razvoj zapadnjačkoga falogokratičnog sustava razmišljanja, autorica lobira za temeljite i korjenite lingvističke, znakovne promjene, da bi se, na taj način, direktnim utjecajem na razvoj i stabilnost kulturnih simbola poništile sve tekovine zapadnjačkoga filozofskog diskursa koje ženu predstavljaju kao zrcalni odraz, odnosno kao »negativ muževne refleksije« (Irigaray 1974: 20). Također, Cavarerina teorija različitosti nadilazi onu biološko-morfološku, ali i bilo koju drugu koja podrazumijeva bipolarne aspekte promatranja, kao i hijerarhijski strukturirane sustave. Spolno i rodno jesu svojevrsne oznake nejednakosti, dakle, različitosti. No, ta različitost ne razdvaja biologiju od kulture, morfologiju i fiziologiju od jezika i govora. Jer ono što nas u konačnici razdvaja ili spaja nije negacija ili priznanje o postojanju različitosti, već divergentni pogledi na te iste različitosti.

\section{Literatura}

Arendt, Hannah (1987): La vita della mente, prev. Giorgio Zanetti, Il Mulino, Bologna.

Battersby, Christine (1989): Gender and Genius. Towards a Feminist Aesthetics, The Women's Press, London.

Battersby, Christine (1998): The Phenomenal Woman. Feminist Metaphysics and the Patterns of Identity, Polity Press, Cambridge.

Beauvoir, Simone de (2016): Drugi spol, prev. Mirna Šimat, Naklada Ljevak, Zagreb.

Blixen, Karen (1959): La mia Africa, prev. Lucia Demby Drudi, Feltrinelli, Milano.

Braidotti, Rosi (2002): Nuovisoggetti nomadi, Sosella, Rim.

Butler, Judith (2000): Nevolje s rodom. Feminizam i subverzija identiteta, prev. Mirjana Paić-Jurinić, Ženska Infoteka, Zagreb.

Cavarero, Adriana (1987): »Per una teoria della differenza sessuale«, u: Diotima et al., Il pensiero della differenza sessuale, La tartaruga, Milano, str. 52-78.

Cavarero, Adriana (1990): Nonostante Platone. Figure femminili nella filosofia antica, Editori Riuniti, Rim.

Cavarero, Adriana (1990): »Dire la nascita«, u: Diotima et al., Mettere al mondo il mondo, La tartaruga, Milano, str. 93-121.

Cavarero, Adriana (1997): Tu che mi guardi, tu che mi racconti. Filosofia della narrazione, Feltrinelli, Milano.

Cavarero, Adriana; Restaino, Franco (2009a): Le filosofie femministe. Due secoli di battaglie teoriche e pratiche, Bruno Mondadori, Milano.

Cavarero, Adriana (2009b): Democrazia Sorgiva. Note al pensiero politico di Hannah Arendt, Raffaello Cortina, Milano.

Cavarero, Adriana (2013): Inclinazioni. Critica della rettitudine, Raffaello Cortina, Milano.

Cixous, Hélène (1975): »The Laugh of the Medusa«, u: Robert Dale Parker (ur.), Critical Theory. A Reader for Literary and Cultural Studies, Oxford University Press, New York - Oxford, str. 242-256.

Cixous, Hélène (1977): »Entretien avec Françoise van Rossum-Guyon«, Revue des sciences humaines 168 (1977) 4, str. 479-493. 
Cixous, Hélène (1998): »Sorties«, prev. Karmen Krajina, u: Zlatko Kramarić (ur.), Književnost, povijest i politika, Svjetla Grada, Osijek, str. 258-266.

Derrida, Jacques (2007): Pisanje i razlika, prev. Vanda Mikšić, TKD Šahinpašić - BTC Šahinpašić, Sarajevo - Zagreb.

Gallino, Tilde Giani (1989): »Le Grandi Madri: un'introduzione al mito e all'archetipo«, u: Tilde Giani Gallino (ur.), Le Grandi Madri, Feltrinelli, Milano, str. 8-32.

Gilbert, M. Sandra; Gubar, Susan; Appignanesi, Lisa (1979): The Madwoman in The Attic: The Women Writer and the Nineteenth Century Literary Imagination, Yale University Press, New Haven (CT).

Gunn, Janet Varner (1982): Autobiography: Toward a Poetics of Experience, University of Pennsylvania Press, Philadelphia.

Heller-Roazen, Daniel (2007): Ecolalie: Saggio sull'oblio delle lingue, prev. Andrea Cavazzini, Quodlibet, Macerata.

Homer, Sean (2005): Jacques Lacan, Routledge, London.

Irigaray, Luce (1974): Spéculum de l'autre femme, Minuit, Pariz.

Irigaray, Luce (1977): Ce sexe qui n'en est pas un, Minuit, Pariz.

Irigaray, Luce (1989): Sessi e genealogie, prev. Lisa Muraro, La tartaruga, Milano.

Jankowski, Elizabeth (1992): »Ascoltare la madre« u: Elizabeth Jankowski et al. (ur.), All'inizio di tutto: la lingua materna, Rosenberg i Sellier, Torino, str. 11-39.

Lepschy, Giulio C. (1989): Nuovi saggi di linguistica italiana, Il mulino, Bologna.

Macola, Eminia (2008): »La lingua madre«, Attualità lacaniana. Rivista della Scuola Lacaniana di Psicoanalisi 8 (2008), str. 189-194.

Miller, Jacques-Alain (1996): »Il monologo de l'apparola«, La Psicoanalisi. Rivista del Campo Freudiano 2 (1996), str. 20-40.

Moi, Toril (2007): Seksualna-tekstualna politika: feministička književna teorija, prev. Maša Grdešić, AGM, Zagreb.

Muraro, Lisa (2006): L'ordine simbolico della madre, Editori Riuniti, Rim.

Saussure, Ferdinand de (2003): Corso di linguistica generale, prev. Tullio De Mauro, Laterza, Rim - Bari.

Sissa, Giulia (1983): »Il corpo della donna: Lineamenti di una ginecologia filosofica«, u: Silvia Campese, Paola Manuli, Giulia Sissa (ur.), Madre Materia, Boringhieri, Torino, str. 81-145.

Stanley, Liz (1992): The Auto/biographical I: The Theory and Practice of Feminist Auto/ biography, Manchester University Press, Manchester.

Steiner, George (1994): Dopo Babele: aspetti del linguaggio e della traduzione, Garzanti, Milano.

Violi, Patrizia (1986): L'infinito singolare: Considerazioni sulle differenze sessuali nel linguaggio, Essedue, Verona.

Zamboni, Chiara (2006): Il cuore sacro della lingua, Il poligrafo, Padova. 


\title{
Astrid Kovačević
}

Sexual and Linguistic in the Work of

\section{Adriana Cavarero: Beyond Equality and Difference}

\begin{abstract}
The paper examines the relationship between the sexual and linguistic and their mutual influence within the fields of political philosophy, linguistics, and theory of text, in selection from Adriana Cavarero's work. First, we begin from the knowledge of poststructuralist text theory, psychoanalytic feminism and psycholinguistics, which are later expanded with the results from political philosophy with special emphasis on ancient texts. Cavarero's texts are being analysed to describe the features through which the relationship between gender, sex and text is established. Through a critical exploration of Cavarero's texts and previous theoretical discussions and the analysis results, a conclusion about the influence of the sexual on language and culture and the influence of language and cultural symbols on social and gender roles is reached.
\end{abstract}

\section{Keywords}

Adriana Cavarero, sexuality in language, linguistic democracy, women's writing, psychoanalytic feminism, mother tongue, female subject, ancient texts 